\title{
MAGNETITE IN SOKLI CARBONATITE MASSIF AND IN TULPPIO OLIVINITE
}

\author{
KYÖSTI HEINÄNEN and HEIKKI VARTIAINEN
}

\begin{abstract}
HEINÄNEN, K. and VARTIAINEN, H. (1981): Magnetite in Sokli carbonatite massif and in Tulppio olivinite. Bull. Geol. Soc. Finland $53-2,83-90$.

Occurrence, ilmenite exsolutions and composition of magnetite in the carbonatite massif of Sokli and in the olivinite of Tulppio have been studied. In the carbonatite massif, magnetite of magmatic carbonatites is hypidio-idiomorphic, contains only very fine-grained ilmenite exsolutions (ulvöspinel), and the minor components $\mathrm{TiO}_{2}, \mathrm{MgO}, \mathrm{MnO}$ and $\mathrm{Al}_{2} \mathrm{O}_{3}$ of magnetite show a decreasing tendency in the successive $\mathrm{I} \rightarrow \mathrm{II} \rightarrow \mathrm{IV}$ magmatic stages. Magnetite of metacarbonatite is xenomorphic, containing a great number of ilmenite exsolutions indicating a complicated thermal history of these rocks. The magnetite of the magmatic carbonatites has lower $\mathrm{TiO}_{2}$ and higher $\mathrm{MnO}$, $\mathrm{Al}_{2} \mathrm{O}_{3}, \mathrm{MgO}$ and $\mathrm{ZnO}$ contents than that of the metacarbonatites, on the average. Magnetite of the Tulppio olivinite is fine-grained, and the minor element contents, excepting $\mathrm{Cr}$ and $\mathrm{Si}$, are lower than those in the carbonatite massif.
\end{abstract}

Kyösti Heinänen, Rautaruukki Oy, SF-92170 Raahensalo, Finland. Heikki Vartiainen, Rautaruukki Oy, SF-96100 Rovaniemi, Finland.

\section{Introduction}

This paper briefly describes the occurence of magnetite in the Sokli carbonatite massif and in the Tulppio olivinite, and presents some microprobe analyses of it. The purpose of the study was to find out the differences, if any, between magnetites representing different rock groups. Samples of the carbonatite complex have been collected from drill holes all over the complex, and a sample of Tulppio olivinite has been taken from a pit about four kilometers southwest from the carbonatite exocontact (Vartiainen, 1980). A detailed geology of the carbonatite massif has been given earlier (Vartiainen, 1980).
K. Heinänen has analyzed magnetite and examined ilmenite exsolutions. H. Vartiainen is responsible for other subjects of this paper.

\section{Occurrence}

Magnetite is a common rock-forming or accessory mineral in almost all rock varieties of the carbonatite massif. It appears as an accessory mineral in the Tulppio olivinite too. The average amounts, grain size, and forms has been summarized in Table 1 .

Magnetite of the Tulppio olivinite differs from that of the rocks of the carbonatite com- 
Table 1. Amount, grain size, and form of magnetite in the rocks of carbonatite massif and in the olivinite of Tulppio.

Amount, average volume- $\%$
Grain size, mm

Grain form
Pre-carbonatite rocks

Olivinite of Tulppio

Magnetite-olivinite

Pyroxenite

Magmatic carbonatites

$\begin{array}{cl}\text { Stage } & \text { I, phoscorite } \\ » & \text { II, sövite } \\ » & \text { III, phoscorite } \\ » & \text { IV, sövite }\end{array}$

Metacarbonatites

Metaphoscorite

Metasilicosövite

Metasomatites

Amphibole rock

Mica-amphibole rock

Mica rock

$$
\begin{array}{r}
1-2 \\
20-40 \\
0-10
\end{array}
$$

$0-1$

$10-50$

$1-5$

$25-35$

$3-6$

$15-25$

$2-5$

$$
\begin{array}{r}
15-25 \\
3-6
\end{array}
$$

$0-5$

$0-10$

$0-20$
$5-10$
$1-5$
$5-10$
$1-5$

$5-20$

$0.5-5$

$0.5-3$

$1-10$

$1-10$ idiom.-hypidiom.

xenomorphic

»

idiom.-hypidiom.

hypidiom.-xenom.

idiom.-hypidiom.

xenomorphic

xenomorphic plex in smaller grain size and lower amount. The largest magnetite grains occur in the magnetite-olivinites of the carbonatite massif where the grain size may rise over $10 \mathrm{~cm}$ (Fig. 1). In general, magnetite of magnetiteolivinite, pyroxenite, metacarbonatites, and metasomatites is granulated, resorbed and veined by carbonates. Replacement by carbonates may be so intense that only the ilmenite lamellae preserved indicate the contours of original magnetite grains (Fig. 2). These characteristics are lacking in the mag- netite of magmatic carbonatites, where magnetite usually is fresh and typified by idiomorphic and hypidiomorphic grain forms. These magnetites may also have been corroded by carbonates but to a much smaller extent than those in the former rocks.

\section{Ilmenite exsolutions}

Titaniferous magnetite commonly contains ilmenite formed by exsolution through the

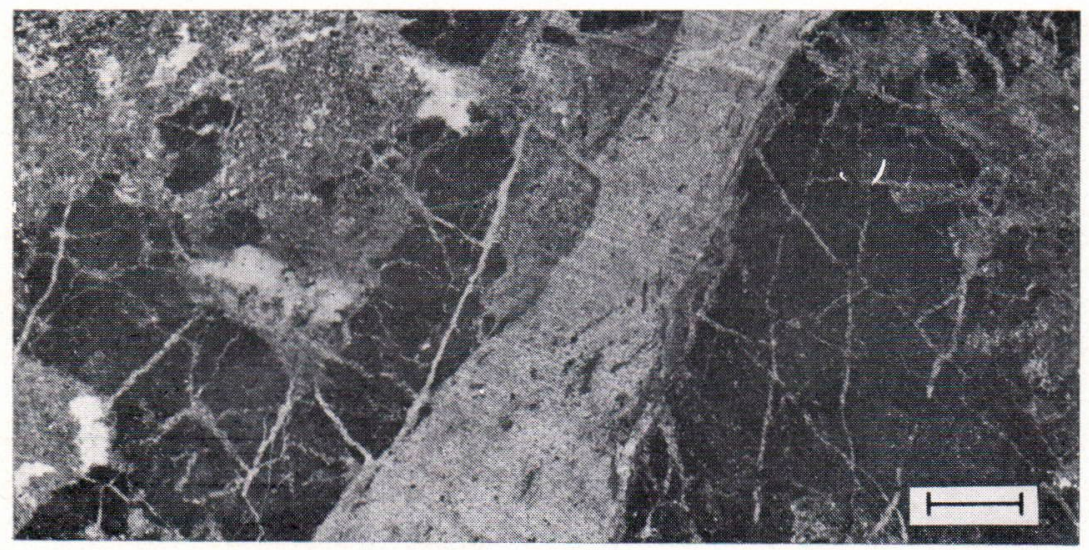

Fig. 1. Moderately phlogopitized magnetite (black) in pegmatoidal magnetite olivinite. Veinlets of carbonate and carbonatite cut the magnetite. Drill hole 436 at 24.0 metres. Scale bar, $1.0 \mathrm{~cm}$. 


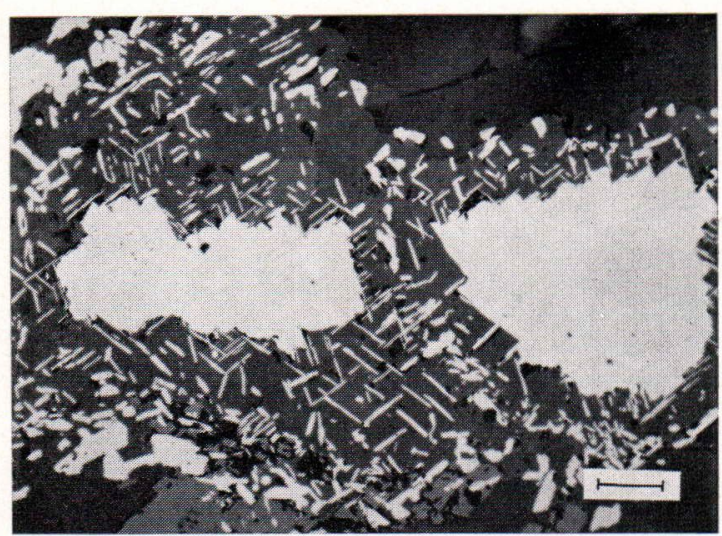

Fig. 2. Partly altered magnetite (light gray) in metaphoscorite derived from pyroxenite. The area of ilmenite lamellae indicate the original contours of magnetite. Drill hole 358 at 219.7 metres. Scale bar, $0.5 \mathrm{~mm}$.

oxidation of an ulvite component of the originally homogeneous single-phase magnetite (Buddington and Lindsley, 1964). There are several generations of ilmenite exsolutions in the magnetite of metaphoscorites of the Sokli massif which can be described as follows:

- coarse granular-like ilmenite, which occurs between magnetite grains and in cracks of magnetite (Fig. 3 A)

- coarse granular ilmenite in magnetite (0.01-0.1 mm, Fig. $3 \mathrm{~B})$

- regular coarse exsolution lamellae (about $0.5 \mathrm{~mm}$ long and about $5 \mu \mathrm{m}$ wide, Fig. $3 \mathrm{~B})$

- regular small exsolution lamellae (about $10 \mu \mathrm{m}$ long, less than $0.5 \mu \mathrm{m}$ wide).

These different types of ilmenite exsolutions occur irregularly in magnetite grains of metaphoscorites, even so that two or three different exsolution types may exist in one and the same grain (Fig. 3 B). The great number of exsolutions indicates that a great part of titanium may have exsolved as ilmenite from magnetite. This is supported by the spot analyses of clean places next to ilmenite exsolutions. According to the analyses the average $\mathrm{TiO}_{2}$ content in the clean places of magnetite ranges between 0.4 and $2.0 \%$.
Lacking of ilmenite exsolutions (Fig. 4 A) makes the magnetite of magmatic carbonatites different from that of the metacarbonatites. A great magnification, however, reveals that this magnetite is unhomogeneous (Fig. 4 B), resembling the ulvöspinel described by Ramdohr (1969, p. 904).

\section{Composition}

Whole magnetite grains were analysed by an electron microprobe analyzer so that a square-shaped scanning area covered as big

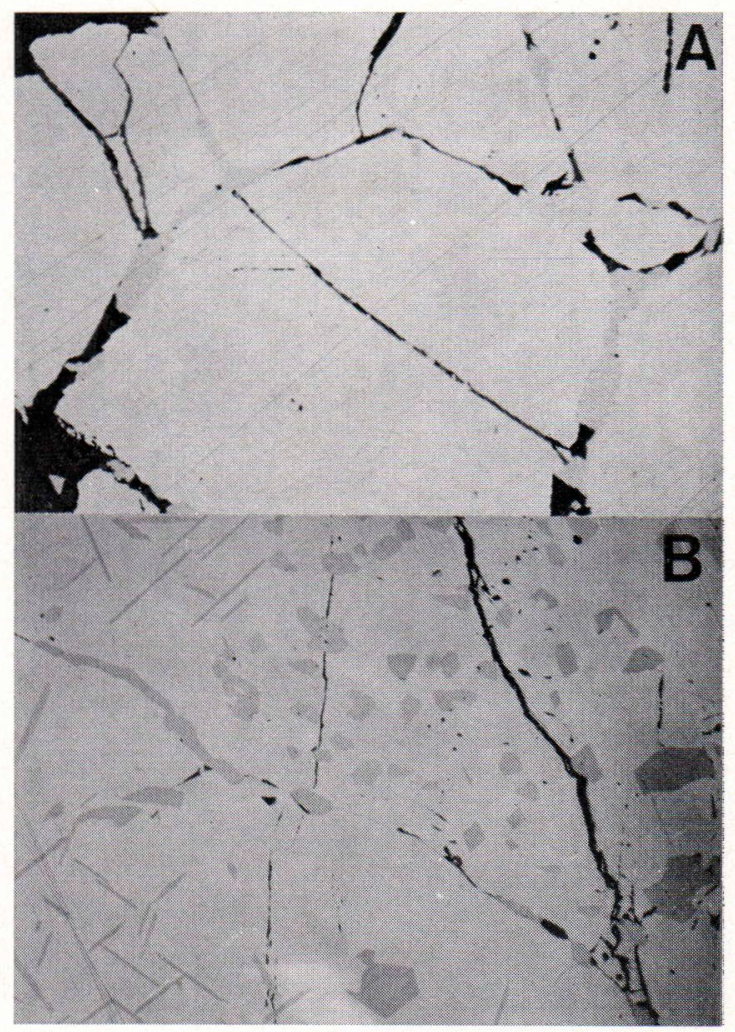

Fig. 3. Ilmenite exsolutions in the magnetite of metaphcscorites. A. Ilmenite exsolutions (medium gray) between magnetite grains (light gray) and in cracks of magnetite. Drill hole 4 at 105.7 metres. Magnification, x 200. B. Coarse, granular ilmenite exsolutions (dark gray on the right) and coarse ilmenite lamellae (left) in one and the same magnetite grain (light gray). Drill hole 358 at 118.5 metres. Magnification, x 200 . 


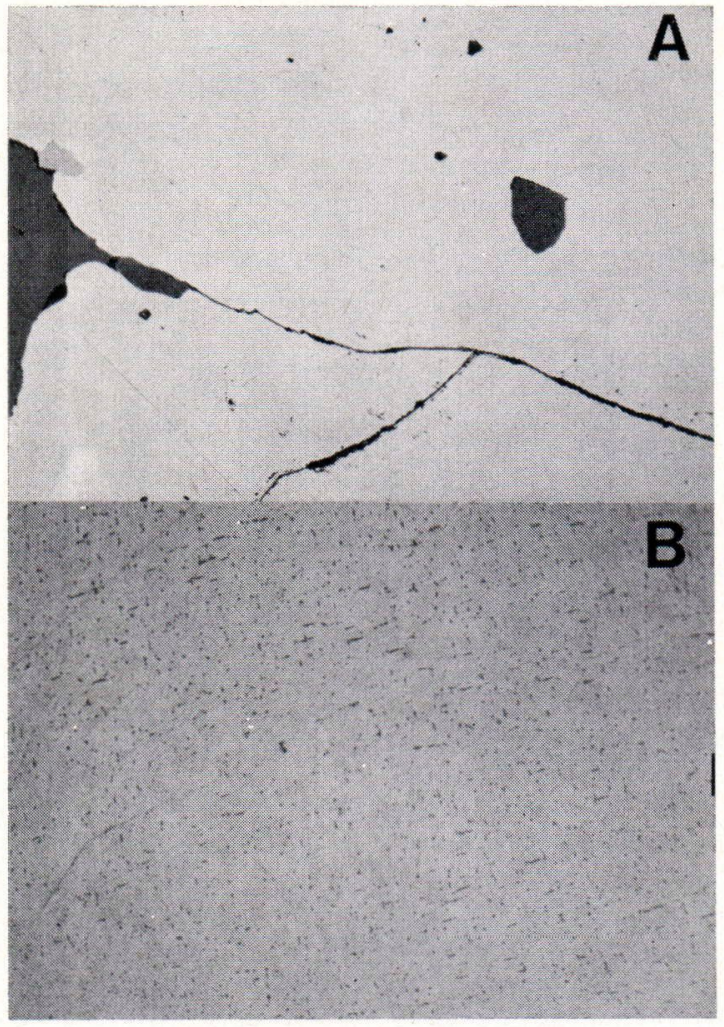

Fig. 4. Magnetite in magmatic phoscorite. Drill hole 250 at 59.7 metres. A. Homogeneous-looking magnetite (light gray). Magnification, x 200. B. A greater magnification of the same grain shows unhomogeneity similar to ulvöspinel. Magnification, x 1000 .

an area of the grain under study as possible. The standard samples were scanned similarly. This method, unlike spot analyses, gives the original composition of magnetite before the exsolution of ilmenite, eliminating the effects of possible compositional zoning in grains. The values given in Table 2 are averages of three grain analyses per sample. There are only slight relative variations between grain analyses in a sample, e.g. the variation of iron is about one per cent and that of $\mathrm{TiO}_{2}$ from 10 to 20 per cent.

The results of the analyses have been arranged according to host rocks in Table 2 . The magnetite of magmatic carbonatites represents rocks from four stages. Because of metasomatic alteration it has been difficult to group metacarbonatitic host rocks. The sample 946-0069 of metaphoscorite of an unidentified origin represents an amphibolerich variant, the sample $946-0072$ a mica-rich variant, and the last two strongly altered, heterogeneous rocks. Both metasilicosövites are tetraferriphlogopite-richterite-bearing types.

The averages of minor components $\mathrm{TiO}_{2}$, $\mathrm{MgO}, \mathrm{MnO}$, and $\mathrm{Al}_{2} \mathrm{O}_{5}$ given in Table 2 have been plotted in Fig. 5. The magnetite of magmatic carbonatites has crystallized in successive generations as follows:

\section{Stage I $\rightarrow$ Stage II $\rightarrow$ Stage IV.}

The magnetite of Stage I is mainly preserved in the Stage III, and therefore the corresponding values are presented separately in Fig. 5. The results indicate that the minor components $\left(\mathrm{TiO}_{2}, \mathrm{MgO}, \mathrm{MnO}, \mathrm{Al}_{2} \mathrm{O}_{3}\right)$ show a tendency to decrease during the crystallization of the magnetite of magmatic carbonatites whereas iron shows a contrary trend. Observations of Table 2 and Fig. 5:

$\mathrm{TiO}_{2}$ : The magnetite of phoscorites (Stage I and III) has a higher $\mathrm{TiO}_{2}$ content (2.4 $5.7 \%$ ) than that of sövites and silicosövites $(1.2-2.1 \%)$. The higher $\mathrm{TiO}_{2}$ content of the Stage III compared to Stage I in Fig. 5 does not necessarily mean an increased $\mathrm{TiO}_{2}$ content, but is more likely due to too few analyses, since high $\mathrm{TiO}_{2}$ values $\left(5 \% \mathrm{TiO}_{2}\right)$ occur also in Stage I (Table 2). Actually, during hydrothermal stage (Stage III), minor components in magnetite lattice have strongly decreased, which is verified by spot microprobe analyses. Two magnetite grains, with magnetite of Stage I enclosed by an altered or recrystallized magnetite phase of Stage III have been analyzed (Fig. 6). The results have been plotted in Fig. 7. $\mathrm{TiO}_{2}$ as well as other minor components $\left(\mathrm{MgO}, \mathrm{MnO}, \mathrm{Al}_{2} \mathrm{O}_{3}\right)$ have clearly decreased. 
Table 2. Whole grain electron microprobe analyses of Sokli magnetites.

\begin{tabular}{|c|c|c|c|c|c|c|c|c|c|c|c|c|c|}
\hline Sample & $\begin{array}{c}\mathrm{DH} \\
\text { no }\end{array}$ & $\begin{array}{c}\text { Depth } \\
\text { m }\end{array}$ & Stage & Rock & $\begin{array}{l}\mathrm{Fe} \\
0 \%\end{array}$ & $\underset{0 \%}{\mathrm{TiO}_{2}}$ & $\underset{0 \%}{\mathrm{MnO}}$ & $\underset{0 \%}{\mathrm{~V}_{2} \mathrm{O}_{3}}$ & $\underset{0 \%}{\mathrm{Cr}_{2} \mathrm{O}_{3}}$ & $\underset{0 \%}{\mathrm{SiO}_{2}}$ & $\underset{0 \%}{\mathrm{Al}_{2} \mathrm{O}_{3}}$ & $\underset{0 \%}{\mathrm{MgO}}$ & $\underset{\%}{\mathrm{ZnO}}$ \\
\hline \multicolumn{14}{|c|}{ Magmatic carbonatites } \\
\hline $946-0017$ & 250 & 59.7 & $\mathrm{I}$ & \multirow{4}{*}{ Phoscorites } & 67.7 & 3.15 & .95 & .19 & .01 & .13 & .48 & 3.11 & \\
\hline $946-0018$ & 289 & 112.1 & $\mathrm{I}$ & & 63.9 & 3.30 & .90 & .28 & .01 & .01 & .20 & 2.67 & \\
\hline $946-0019$ & 281 & 58.0 & I & & 65.1 & 5.01 & .84 & .12 & .01 & .44 & .84 & 3.20 & .11 \\
\hline $946-0020$ & 260 & 77.0 & $\mathrm{I}$ & & 67.1 & 2.43 & .74 & .21 & .01 & .02 & .25 & 2.85 & .10 \\
\hline $946-0027$ & 250 & 128.8 & II & \multirow{5}{*}{$\begin{array}{l}\text { Sövites and } \\
\text { silicosövites }\end{array}$} & 66.6 & 1.21 & .77 & .14 & .01 & .05 & .85 & 3.61 & .10 \\
\hline $948-1039$ & 374 & 230.5 & II & & 67.8 & 1.99 & .84 & .13 & .01 & .01 & .51 & 2.83 & .08 \\
\hline $948-0128$ & 433 & 166.4 & II & & 69.4 & 1.68 & .48 & .14 & .01 & .01 & .41 & 1.10 & .08 \\
\hline $946-0031$ & 261 & 44.0 & II & & 69.1 & 1.50 & .45 & .16 & .01 & .01 & .53 & 1.41 & .09 \\
\hline $946-0032$ & 358 & 200.1 & II & & 70.3 & 1.55 & .37 & .14 & .01 & .02 & .43 & 1.41 & .08 \\
\hline $946-0035$ & 329 & 183.0 & III & \multirow{4}{*}{ Phoscorites } & 67.1 & 5.75 & .57 & .22 & .01 & .02 & .13 & .86 & .12 \\
\hline $946-0036$ & 331 & 37.2 & III & & 67.8 & 5.40 & .53 & .22 & .02 & .07 & .13 & 1.10 & .12 \\
\hline $946-0038$ & 332 & 84.2 & III & & 68.9 & 3.41 & .56 & .17 & .01 & .01 & .13 & 1.20 & .11 \\
\hline $946-0039$ & 340 & 135.5 & III & & 68.4 & 3.01 & .49 & .34 & .01 & .02 & .10 & .98 & .11 \\
\hline $946-0042$ & 340 & 131.9 & IV & \multirow{3}{*}{$\begin{array}{l}\text { Sövites and } \\
\text { silicosövites }\end{array}$} & 69.8 & 1.46 & .16 & .31 & .01 & .02 & .23 & .44 & .03 \\
\hline $946-0043$ & 342 & 110.2 & IV & & 68.8 & 2.15 & .57 & .20 & .01 & .02 & .17 & 1.59 & .10 \\
\hline $946-0044$ & 359 & 232.2 & IV & & 69.6 & 1.44 & .26 & .25 & .01 & .01 & .10 & 1.10 & .09 \\
\hline
\end{tabular}

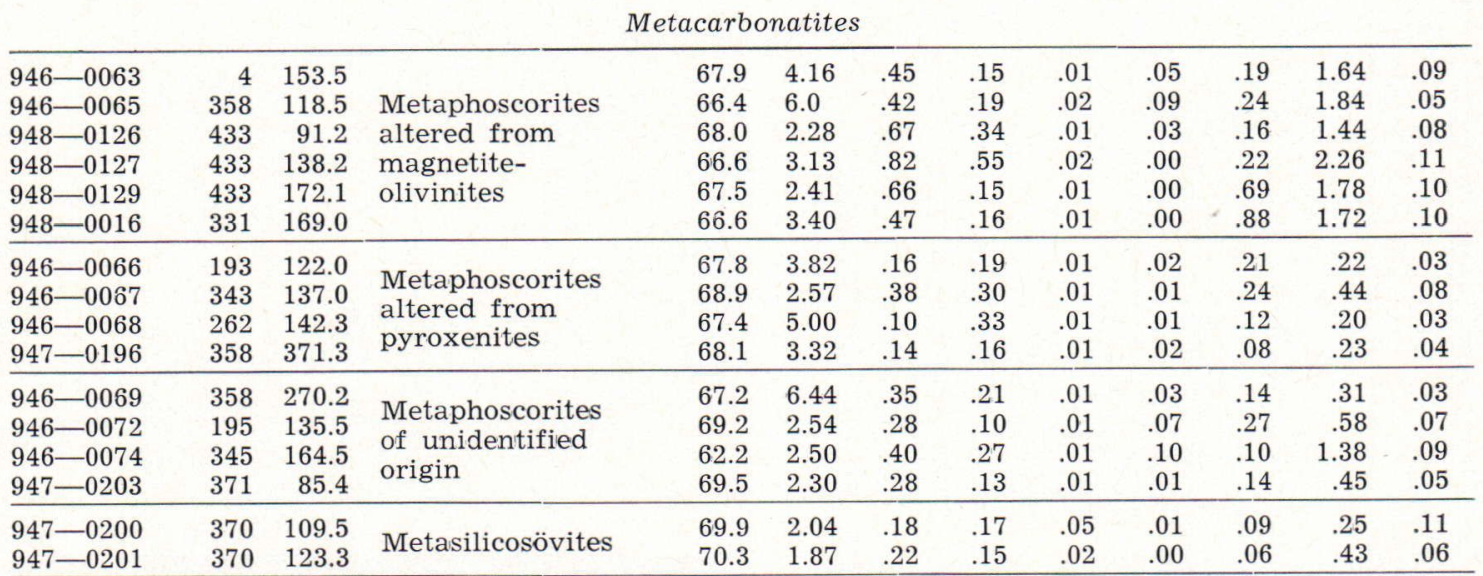

Tulppio olivinite

\begin{tabular}{|c|c|c|c|}
\hline $948-1040$ & Pit $26 / \mathrm{MH} / 67$ & Olivinite & .04 \\
\hline
\end{tabular}

All metaphoscorites are characterized by high $\mathrm{TiO}_{2}$ contents $(2.3-6.4 \%)$. The highest $\mathrm{TiO}_{2}(6.4 \%)$ contents in the Sokli magnetite derives from the metaphoscorite (sample 9460069, Table 2). The magnetite of metasilicosövites has a lower $\mathrm{TiO}_{2}$ content (about $2.0 \%$ ) than that of the metaphoscorites.

$\mathrm{MgO}, \mathrm{MnO}$, and $\mathrm{Al}_{2} \mathrm{O}_{3}$ : The $\mathrm{MgO}$ and $\mathrm{MnO}$ contents in the magnetite of the magmatic carbonatites distinctly decrease towards younger generations excepting $\mathrm{Al}_{2} \mathrm{O}_{3}$ which deviates from this trend in Stage II. The $\mathrm{Al}_{2} \mathrm{O}_{3}$ values in Table 2 suggest that $\mathrm{Al}_{2} \mathrm{O}_{3}$ contents are at the same level in Stage I and II but lower in Stage III and IV.

In metacarbonatites, the magnetite of metaphoscorite originating from the magnetiteolivinite differs from the other metaphoscorites with regard to higher $\mathrm{MgO}, \mathrm{MnO}$, and $\mathrm{Al}_{2} \mathrm{O}_{3}$ contents. The magnetite of metasilicosövites is more decreased in these components than in the metaphoscorites. Be it no- 


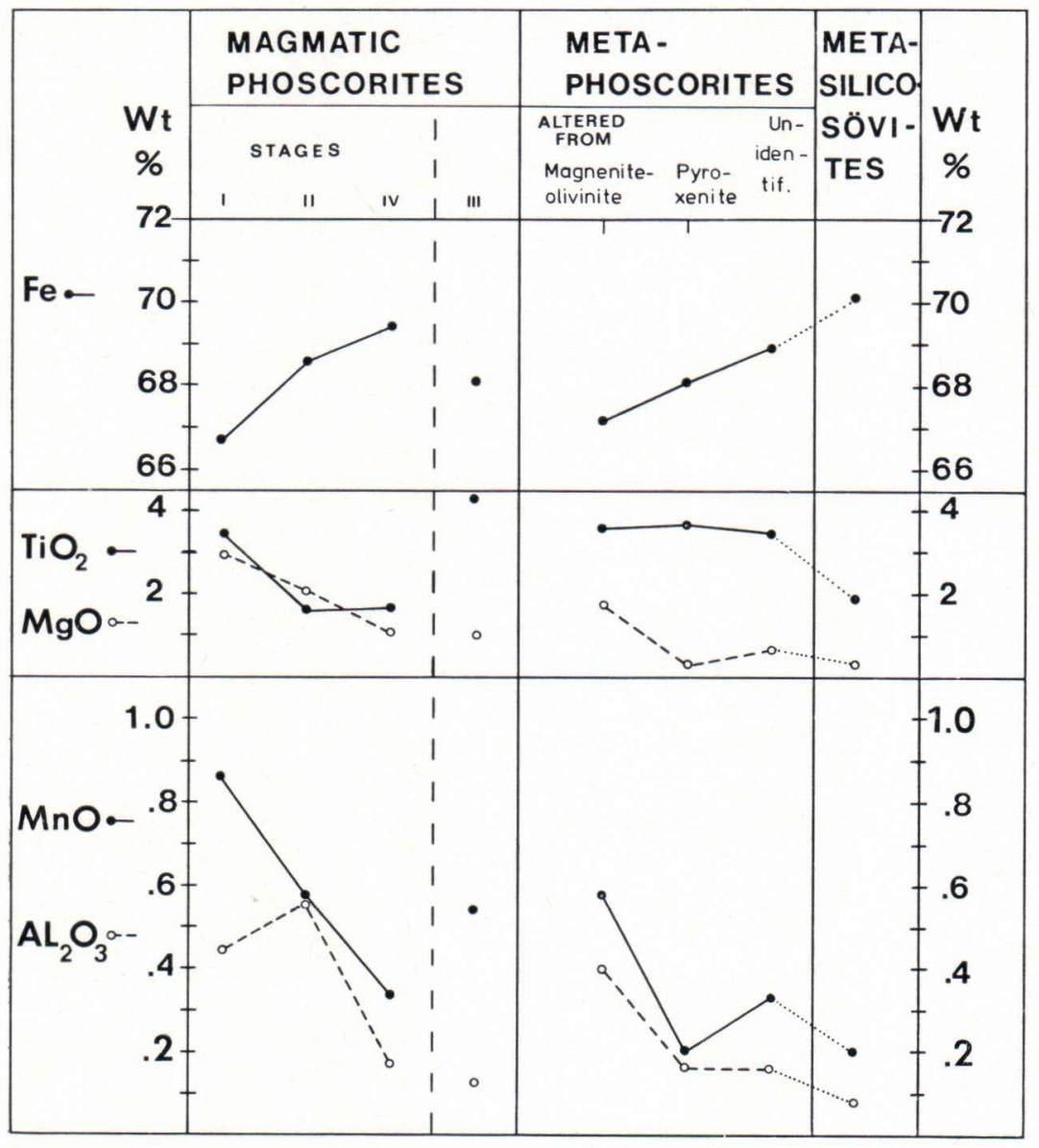

Fig. 5. Variation in minor elements of the magnetite of magmatic carbonatites and metacarbonatites.

ticed that the magnetite of metasilicosövites contains more $\mathrm{TiO}_{2}$ and less $\mathrm{MgO}, \mathrm{MnO}$, and $\mathrm{Al}_{2} \mathrm{O}_{3}$ than the magnetite of magmatic sövites and silicosövites.

$\mathrm{V}_{2} \mathrm{O}_{3}$ : The average contents of $\mathrm{V}_{2} \mathrm{O}_{3}$ in magnetite of different rock groups range from 0.14 to $0.25 \%$ and in separate analyses from 0.13 to $0.33 \%$. The exceptionally high value of $0.55 \%$ comes from metaphoscorite originating from magnetite-olivinite (sample 9480127 / DH 433 / 138.2). Two other magnetites representing the same drill hole give normal values.

$\mathrm{Cr}_{2} \mathrm{O}_{3}: \mathrm{Cr}_{2} \mathrm{O}_{3}$ stays stabile in all magnetites i.e. between 0.01 and $0.02 \%$ excepting in metasilicosövite, where it rises up to $0.05 \%$.

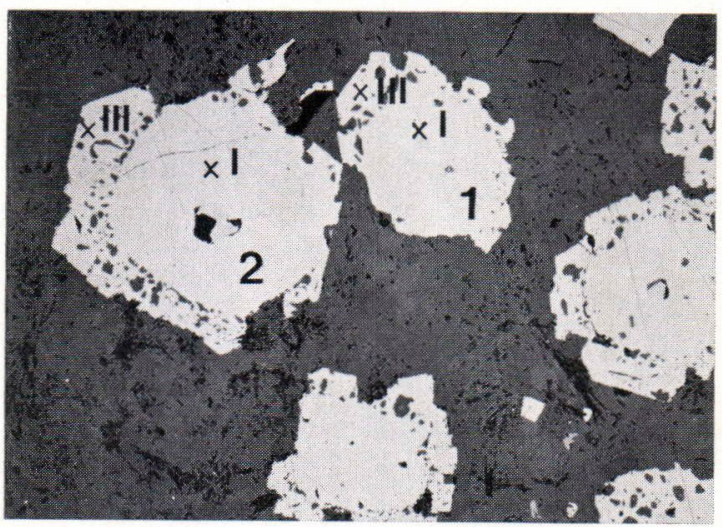

Fig. 6. Altered or recrystallized magnetite of Stage III enclosing the primary magnetite of Stage I. Symbols: $x$ I $=$ Analysed point of Stage I magnetite; $\mathrm{x}$ III $=$ Analysed point of Stage III magnetite. Drill hole 331 at 37.2 metres. Magnification, x 100 . 


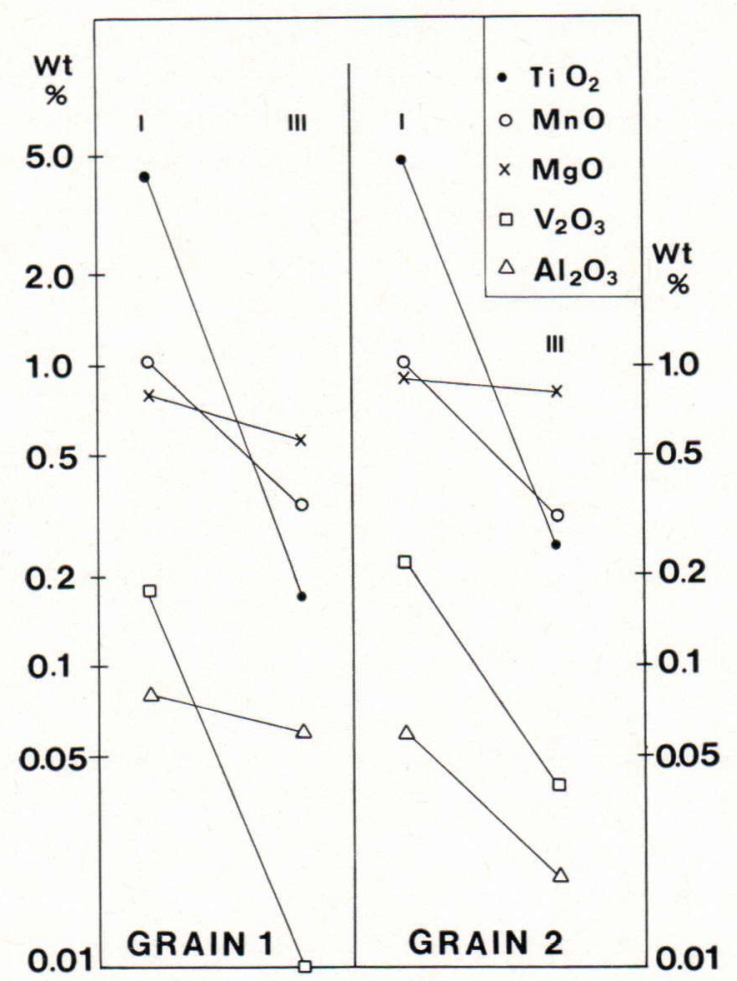

Fig. 7. Variation in the minor elements of magnetite grains in Stage III phoscorite. I = Stage I magnetite; III = Stage III magnetite. Analysed points are seen in Fig. 6.

$\mathrm{SiO}_{2}$ : The values below $0.13 \%$ may represent the real $\mathrm{SiO}_{2}$ contents in a magnetite lattice. The high value of $0.44 \%$ for the sample 946-0019 may be due to a silicate inclusion, to which refers also the high $\mathrm{Al}_{2} \mathrm{O}_{3}$ content $(0.84 \%)$ as compared with the average $(0.44 \%)$ of Stage I phoscorites (Table 2).
$\mathrm{ZnO}$ : Magnetites of magmatic carbonatites have higher $\mathrm{ZnO}$ contents, i.e. 0.07 to $0.12 \%$ than those of the metacarbonatites, i.e. 0.05 to $0.09 \%$, on the average.

\section{Discussion}

The magnetite of magmatic carbonatites is characterized by an idiomorphic-hypidiomorphic habit and a grain size of 1 to $10 \mathrm{~mm}$. The magnetite of metacarbonatites, deriving from pre-carbonatitic rocks, shows granulation of originally big crystals (diameter up to $10 \mathrm{~cm}$ ), the grains are veined and replaced by carbonates and micas. Besides, the chemistry of these magnetites shows some differences. The magnetite of the magmatic carbonatites has lower $\mathrm{TiO}_{2}$ and higher $\mathrm{MnO}$, $\mathrm{Al}_{2} \mathrm{O}_{3}, \mathrm{MgO}$ and $\mathrm{ZnO}$ contents than that of the metacarbonatites on the average. The contents of all minor elements, excepting $\mathrm{Cr}$ and $\mathrm{Si}$, in the magnetite of Tulppio olivinite are lower than those in the former rocks (Table 3).

A great number of ilmenite exsolutions in the magnetite of metacarbonatites refers to a complicated thermal history of these rocks. The ilmenite exsolutions in the magnetite derived from the pre-carbonatitic magnetite olivinite and pyroxenite may be partly original, partly produced during thermometamorphism caused by carbonatite intrusion.

Table 3. Average composition of magnetite in magmatic carbonatites, metacarbonatites, and Tulppio olivinite.

\begin{tabular}{|c|c|c|c|c|c|c|c|c|c|}
\hline & $\begin{array}{l}\mathrm{Fe} \\
0 \%\end{array}$ & $\underset{0 / 0}{\mathrm{TiO}_{2}}$ & $\underset{0 \%}{\mathrm{MnO}}$ & $\underset{0 \%}{\mathrm{~V}_{2} \mathrm{O}_{3}}$ & $\underset{0 \%}{\mathrm{Cr}_{2} \mathrm{O}_{3}}$ & $\underset{0 \%}{\mathrm{SiO}_{2}}$ & $\underset{0 \%}{\mathrm{Al}_{2} \mathrm{O}_{3}}$ & $\underset{0 \%}{\mathrm{MgO}}$ & $\underset{0 \%}{\mathrm{ZnO}}$ \\
\hline \multicolumn{10}{|l|}{ Magmatic } \\
\hline $\begin{array}{l}\text { Meta- } \\
\text { carbonatites } \\
\text { Tulppio }\end{array}$ & 68.6 & 3.16 & .33 & .21 & .02 & .03 & .20 & .77 & .07 \\
\hline olivinite & 71.5 & .08 & .02 & .04 & .04 & .07 & .08 & .40 & .04 \\
\hline
\end{tabular}


The magnetite of magmatic carbonatites contains plenty of ulvite but only little ilmenite. This magnetite probably is in its original state, indicating that no stronger metamorphism has taken place after the intrusion of carbonatite.

The variation in the occurence, composition and exsolution of magnetite of separate rock groups refers to differences in the crystallization environment and the geological history of the host rocks of magnetite.

Composition of the magnetite of carbonatites has been studied by Prins (1972). He concludes that the magnetite of carbonatites contains less trace elements ( $\mathrm{MnO}, \mathrm{MgO}$, $\mathrm{Al}_{2} \mathrm{O}_{3}, \mathrm{~V}_{2} \mathrm{O}_{3}$ and $\mathrm{CaO}$, whose total average is $2.3 \mathrm{wt}-\%$ ) than the magnetite of salic rocks $(4 \mathrm{wt}-\%)$. The averages $\left(\mathrm{MnO}, \mathrm{MgO}, \mathrm{Al}_{2} \mathrm{O}_{3}\right.$, $\mathrm{V}_{2} \mathrm{O}_{3}, \mathrm{Cr}_{2} \mathrm{O}_{3}$ and $\mathrm{ZnO}$ ) of the magnetite of Sokli magmatic carbonatites and metacarbonatites (Table 3 ) are $3.00 \mathrm{wt}-0 \%$ and $1.6 \mathrm{wt}-\%$, respectively. According to Prins (1972) homogeneous magnetite of carbonatite contains $1 \mathrm{wt}-\% \mathrm{TiO}_{2}$ on the average, and magnetite carrying exsolved ilmenite not more than $6 \mathrm{wt}-\%$. With regard to composition (average $\mathrm{TiO}_{2}$ from 2.78 to $3.6 \mathrm{wt}-0 \%$ ) the magnetite of Sokli carbonatite complex can be regarded as a typical magnetite of carbonatite. Deans and Seager (1978) have presented analyses of magnetite of volcanic carbonatites. They show above the average $\mathrm{V}_{2} \mathrm{O}_{3}$ content

\section{References}

Buddington, A. F. and Lindsley, D. H., 1964. Irontitanium oxide minerals and synthetic equivalents. J. Petrol. 5, 310-357.

Deans, T. and Seager, A. F., 1978. Stratiform magnetite crystals from volcanic carbonatites in Tanzania, Kenya, Greenland, and India. Mineral. Mag. 42, 463-475.

Dissanayake, C. B. and Vincent, E. A., 1972. Zinc in rocks and minerals from the Skaergaard intrusion, East Greenland. Chem. Geol. 9, 285297.
$(0.33$ wt- $\%$ ) and below the average $\mathrm{MgO}$ $(0.26 \mathrm{wt-} \%)$ and $\mathrm{Al}_{2} \mathrm{O}_{3}(0.11 \mathrm{wt-} \%)$ contents as compared to the Sokli averages, which are: $0.21,1.28$, and 0.26 wt- $\%$, respectively.

Using electron microprobe spot analyses Prins (1972) has shown that carbonatite magnetite is strongly zoned which results from decreasing of $\mathrm{Ti}, \mathrm{Mn}$ and $\mathrm{Mg}$ from the middle towards the edges of magnetite grains, but $\mathrm{V}$ and $\mathrm{Al}$ do not show any clear trends. Even in the composition of crystallizing carbonatite magma the decreasing of $\mathrm{Ti}$, $\mathrm{Mn}$ and $\mathrm{Mg}$ seems to be a general trend. The results of the Sokli whole grain magnetite analyses (Fig. 5) support these observations. During crystallization of Sokli magmatic carbonatites, $\mathrm{V}, \mathrm{Cr}$ and $\mathrm{Zn}$ have not changed, but thereafter $\mathrm{Zn}$ was enriched in late carbonatite veins of Stage $\mathrm{V}$ forming an independent mineral (sphalerite).

Dissanayaka and Vincent (1972) have found out that zinc is enriched in the ultimate residual magmatic fractions of basic igneous complex of Skaergaard but this has been a continuous process.

Acknowledgements - We are indebted to the Rautaruukki Oy for permission to publish this paper. Mrs. M. Räsänen has checked the language of the manuscript and Miss M. Lantto drew the figures.
Prins, P., 1972. Composition of magnetite from carbonatites. Lithos 5, 227-240.

Ramdohr, P., 1969. The ore minerals and their intergrowths. Braunschweig. Pergamon Press. $1174 \mathrm{p}$.

Vartiainen, H., 1980. The petrography, mineralogy and petrochemistry of the Sokli carbonatite massif, northern Finland. Geol. Surv. Finland. Bull. 313. 126 p.

Manuscript received, April 4, 1981. 